\title{
The Configuration of Speaking: The Hermeneutics of Idiomatic Knowledge
}

\author{
Jesús Martínez del Castillo \\ Dept. of Philology, Almería University, Almería, Spain
}

Tel: 34-950-015-390 E-mail: jesus.gerardo@ual.es; apofansis@msn.com

Received: June 6, 2016 Accepted: July 16, 2016 Published: July 20, 2016

doi:10.5296/elr.v2i2.9560 URL: http://dx.doi.org/10.5296/elr.v2i2.9560

\begin{abstract}
Idiomatic knowledge, the competence of speakers to speak consists of nine aspects perfectly to be separated through abstraction in accordance with two sets of criteria to be found in the activity of speaking: three levels (universal, historical or particular and individual) and three points of view (activity, knowledge and product). Combining the three levels with the three points of view with the aspects referred to they are speaking in general, speaking a particular language and speaking individually; elocutive knowledge, idiomatic knowledge, and expressive knowledge; and the total manifestations of speaking, abstract language and text. My purpose now is to analyze the activity of speaking in order to know if idiomatic knowledge is structured or not thus interpreting the idiomatic knowledge underlying speaking.
\end{abstract}

Hermeneutics is the science consisting in the interpretation of human facts in terms of the human life. Hermeneutics tries to justify what has already been made by humans.

Key words: technique of speaking, external and internal equilibrium, the functional language, the architecture and the structure of a language, homogeneity and diversity.

\section{The Problem}

Apparently idiomatic knowledge appears as something with no structure in a strict sense. Idiomatic knowledge is constituted by three levels, they all interfering with one another. Elocutive knowledge and idiomatic knowledge interfere with each other at any time. It is usually said that linguistic signs are arbitrary. The problem thus is to explain what arbitrary means when applied to linguistic signs. Many irregular forms are due to this constant interfering between elocutive and idiomatic levels. Idiomatic knowledge and expressive knowledge interfere with each other as well. And elocutive knowledge and expressive knowledge are not structured in a strict sense but in a broad sense. In them you had rather find out the rules describing the verbal behavior of speakers than guessing the rules of 
grammar.

But as a matter of fact idiomatic knowledge is structured in a strict sense. In the so-called elocutive knowledge at the universal level you can only find an external coherence, that is, coherence with the principles of knowledge and the knowledge of things. In the expressive level (individual level) you can find an external coherence as well, coherence with the purposes and circumstances affecting speaking. Properly speaking the structure of idiomatic knowledge is to be found at the level of a particular language. At this level two disparaging tendencies or dimensions coexist, the dimensions of homogeneity and diversity. In idiomatic knowledge you can find irregularities and rules with a wide range of application, deviations and exceptions. Idiomatic knowledge is not unitary either in the historical language or in any functional language (see below).

\section{The Configuration of Idiomatic Knowledge}

In order to study idiomatic knowledge (or competence, in as much as it involves activity) it is necessary to establish a double process of abstraction imposing perspectives on the speech of speakers and extracting conclusions. Since the speech of speakers is homogeneous it is necessary, first, to establish the conditions and criteria dealt with by speakers aimed at reaching homogeneity thus neglecting variety in their speech. And, once homogeneity is established, second, it is necessary to analyze the internal relationships given in speech in order to see what is common in the language spoken. In other words: it is necessary to find out the degree of commonness in the language being used at the moment of the production of speech.

The language spoken by speakers is a completely homogeneous language, the so-called the functional language (Coseriu, 1981, 1992), that is, the only type of a language able to function or be spoken. In the determination of the functional language, got through abstraction out of speaking selecting homogeneity and neglecting variety, it is necessary to distinguish two types of equilibrium, the external equilibrium of speaking and the internal equilibrium of speaking, both to be found in the language actually spoken, that is, in the functional language. The external equilibrium has to do with all aspects and parts forming the historical language. In this sense the functional language represents the delimitation of speaking from the point of view of the external conditions of speaking thus forming the equilibrium of speaking. The purpose of this delimitation is finding out the only language able to be actually spoken. For example, speakers speak British English, or American English, or Cokney or Australian English, not a mixture of them all.

The external equilibrium of speaking constitutes the so-called by Coseriu the architecture of a language. It has to do with all elements constituting the synthesis of idiomatic knowledge out of the different systems in a language in connection with the dialects, levels and styles of speech constituting a particular language, they all considered in a state of the language, that is, within synchrony. The architecture of a language is nothing but the manifestation of the diversity to be found within a particular language. Variety in the English language, for example, is to be determined in terms of the different dialects spoken, British English, American English, Cockney; the different levels of speech, standard language, the language of doctors, legal jargon, computer jargon, etc.; and the different styles of speech, formal and informal speech, the family jargon, the jargon of gangsters, etc. 
On the contrary, the structure of a language represents the internal equilibrium of speaking. The structure of a language is only possible in the functional language in a strict sense, that is, in the completely homogeneous language. The architecture of a language consists in delimiting the homogeneity necessary for speakers to understand one another. That is, stable and unitary relationships are only to be found internally, that is, in a functional language (Coseriu, 1992). For example, if you speak formal English you cannot introduce words and expressions not accepted in formal language.

\section{The External Equilibrium of Idiomatic Knowledge}

The architecture of the technique of speaking insofar as it represents the external equilibrium of the technique of speaking constitutes the synthesis of idiomatic knowledge, determined, within synchrony, by three sets of differences:

1) diatopic differences, or the differences in the technique of speaking determined by the language spoken in the different territories where the language is spoken. The unit of speech determined by the set of differences in force a particular territory is a dialect, accent or dialectal accent. A particular or historical language especially if that language is spoken in different territories is constituted by a group of dialects. English, Spanish, French, German, Italian are constituted by different dialects. A dialect is a syntopic language;

2) diastratic differences or levels of speech in the technique of speaking determined by the different social strata in connection with the disciplines or fields of knowledge they are constituted by. For example, the language of doctors, architects, engineers, lawyers, fishermen, etc. These languages (jargons) do not have geographic definition. A particular level of speech constitutes a synestratic language;

3) and diaphasic differences or styles of speech, the differences determined with the contexts and situations in speech. For example, formal speech or informal speech, family jargon, religious language, etc. These functional languages do not have geographic definition but include regional differences. A particular style of speech is a symphasic language.

Any technique of speaking uniform and homogeneous under these three sets of differences, that is, a syntopic, synestratic and symphasic language is a functional language, the language spoken in a particular territory, level of speech and style of speech. It is a completely homogenous language, the only language able to be spoken. Every speaker knows several functional languages. For example, a particular speaker in London may know Cockney and standard English, the jargon in his professional field, formal language and informal language, may know how to speak to children or the elderly, may speak the jargon used in his family and understand the administrative jargon, etc. In Spanish formal language strikingly changes from informal language when addressing someone you do not know. You say, ¿viene Vd. conmigo? instead of the informal, ¿vienes tú conmigo? The contrary would mean the lack of the due respect.

In accordance with this process of abstraction extracted from speaking the following types of functional languages can be found in any language. Standard language the functional language accepted in a particular language or territory. The model language the functional language accepted as a model for speakers to speak. The evaluations made on speech by speakers are based on the model language. It does not usually have dialectal variety but is 
determined diaphasically since it is usually spoken in different levels of speech. Since any speaker has several functional languages they do have several model languages. This can be seen, for example, in actors, who sometimes play the role of a beggar, or a firm leader, or a peasant.

In order to determine what a functional language is like, you have to say that a functional language is an ideal model used by speakers. As such it has only virtual existence as a knowledge. With this we can deduce that the terms functional language, standard language and model language are relative to the cultural level of speakers. A particular speaker who has not ever abandoned his native town has different models to evaluate speech. In this sense for him the model language in particular will be different from the model language of someone who has a higher level of information. But this is not a problem in linguistics. The purpose of linguistics is to describe the verbal behavior of speakers in order to interpret linguistic facts in terms of the human life. Linguistics thus is hermeneutics.

The architecture of a language relates to the multiple techniques of speaking existing in a historical language, that is, it relates to the different dialects, levels and styles of speech in a language. In the architecture of a language there is diversity, that is, there are analogous terms (signifiers) for different meanings (signified). For example, in American English when referring to the ground floor you say the first floor. In the same way when referring to luggage you say baggage; a filling station is a gas station, to lay the table is to put the table. That is, you have the same meanings (signified) but analogous terms (signifiers).

In the architecture of a language there are different techniques of speaking with different traditions in the technique of speaking. For example, the tradition of speaking Spanish in America, is different from the tradition of speaking in Spain. Similarly, in the architecture of a language there are different functional languages. As a matter of facts historical languages constitute a set of functional languages. As a consequence, the different techniques of speaking in a historical language must be considered different languages, that is, they are to be dealt with and analyzed separately.

\section{The Internal Equilibrium of Idiomatic Knowledge. The Structure of a Technique of Speaking or the Structure of a Functional Language}

The process of abstraction initiated above is to be resumed up to separate the common from the individual in speaking. The aim now is to define the functional language thus separating it from speech.

A technique of speaking is to be understood as the usual performances of a language, that is, as the actual use of a homogenous complex of procedures and forms that insofar as they are performed and at the same time they are functional it constitutes an independent notional object. In this sense the technique of speaking is to be distinguished from speech because the technique of speaking in as much as it is knowledge (competence) underlies speech. Since the performance of speech is necessarily individual it contains and manifests the technique of speaking as idiomatic knowledge. The individual performance is to be distinguished from speech because of a double operation of abstraction:

a) abstracting, that is, neglecting the particularity and subjectivity of the individual performance of speech thus selecting what is left; and 
b) abstracting the different performances, that is, neglecting the diversity existing in a speech community thus selecting what is common (Coseriu, 1992, 293-294).

In this way the technique of speaking is to be separated from the speech it underlies. This double operation of abstraction lets us distinguish the following levels in the technique of speaking (from the lowest to the highest just following with the same procedure of abstracting): discourse, the norm of a language, the system of a language and the type of a language.

\subsection{Discourse}

Discourse relates to the actual performance of the activity of speaking, that is, the innumerable speech acts occurring in a speech community. Imagine the lots and lots of speech acts uttered or written in a day in any language. Discourse encompasses anything individual having to do with the performance of speaking at the phonological, morphological, syntactic and semantic levels. In discourse there is contextual and situational variation. For example, with the word wall, you can find the following senses determined by contextual and situational determinations:

a) the one embracing a town, the old wall of Jerusalem

b) the one separating a property, the wall surrounding the property

c) the one separating a room from another one, you can divide the large room with a wall in the middle

d) the one constituted by a cutting in the ground, the train passes through a cutting the walls of which are very high.

e) the one in particular rocks, some birds make their nests on the wall of rocks.

\subsection{The Norm of a Language}

The norm of a language is the technique of speaking considered as a complex of usual or normal performances of speech. It is the language actually performed and constituted in a tradition in the technique of speaking. The usual or normal meanings, forms and procedures, and the usual or normal combinations in speaking belong to the norm of a language. The norm of a language fixes as usual or normal one of the many possible variations in a particular language stating which ones are unusual or have a particular value in a particular aspect.

Properly speaking the norm of a language constitutes the lowest level in the structure of idiomatic knowledge because discourse as such is not structured. The norm of a language constitutes the nearest level to the individual performances of speech or idiomatic knowledge. All descriptions of a language are to be made within the norm of the language. The norm of a language extends to all levels of language description, that is, phonology, morphology, syntax and semantics (Coseriu, 1981; Coseriu, 1992). For example, at the level of meaning the following facts of the norm of a language can be found:

\section{He drinks}

This expression could be tautological in the sense that all human beings must drink if they want to survive. If you say that someone drinks water you state something tautological and unnecessary. But this one is not the sense of the statement. The sense is that he drinks alcohol. 
Because of this the expression constitutes a fact of language or a fact of the norm of a language, since it belongs to the language actually performed and constituted in a tradition in the technique of speaking. Speakers interpret this expression in the way stated since speakers rely on the principle of coherence and confidence (see Martínez del Castillo 2016d) thus constituting a traditional interpretation.

In a similar way at the level of semantic description of English the following example constitutes another fact of the norm of the language,

\section{2. ... animals before the cruel knife of the slaughter (CCELD)}

In accordance with the meaning of cruel the word cannot be applied to a non-human inanimate object such as a knife. There must be someone who makes a voluntary action of causing harm to a sensitive living creature. Since slaughter when applied to farm animals for their meat is considered as something natural and necessary the sense of the example is nothing but reminding the listener of the inevitable thus expressing compassion for farm animals.

The usual performances of meaning, that is, the different ways in accordance with a particular meaning is created following the rules in the system of the language ( $\S$.4.3.) belong to the norm of a language. In the norm of a language the different variants admitted by the system of the language are fixed thus constituting usual performances. This applies both in the form and contents of the word or expression being analyzed thus giving the distinction between main and subsidiary meanings in a word and in the selection of synonyms with a stylistic value (Coseriu 1992). The selection between dog and hound, old and ancient, new and brand-new in English, for example, belongs to the norm of the language.

The norm of a language extends to the phonological description of the language. The way the following words are pronounced constitutes a fact of the norm of the language:

\section{Act, empty, cub-pack, begged, that time}

In these examples there is no plosion of respectively the phonemes $/ \mathrm{k} /$ or $/ \mathrm{p} /, / \mathrm{b} /, \mathrm{g} /$ or $/ \mathrm{t} /$. Only the stops of these phonemes are uttered not the full plosion of them. Another fact of the norm of a language at the level of phonological description is the difference in pronunciation of the following words

\section{Peat, pit, pet, part, pot, put, puff, perfect different from \\ 5. $\quad$ Speed, spit, specimen, span, spot, spin, spun, spurt}

The $/ \mathrm{p} /$ sounds in 4 are pronounced with a considerable puff of breath; however, the $/ \mathrm{p} /$ sounds in 5 are pronounced with little puff of breath.

The so-called irregular forms of verbs and nouns constitute facts of the norm of a language at the level of the formation of words, that is, the level of morphology,

\section{Learnt, leapt, led, caught}

And finally the norm of a language can also be found at the level of the combination of words. For example, the usual word order in English is $\mathrm{S}+\mathrm{V}+\mathrm{O}$. This constitutes a fact of the language that due to its regularity is to be assigned to the system of a language (see determination below). However, you can find many examples not following this rule. For example, 


\section{MInstitute ${ }^{\text {Mink }}$}

7. She smokes, and so do I; She does not say lies, nor do I; I can sing, and so can she. He will come early, and so will they

In a similar way the usual word order for adjectives is to be placed before the headword, that is, the noun but there can be found lots of examples not following this rule. Examples

8. Knight errand, secretary general, heir apparent, the president elect, attorney general, from time immemorial, vice-chancellor designate, court martial, notary public, body politic.

Summing up the norm of a language refers to the set of norms, rules and procedures, systematic or not but functional and oppositional by virtue of which a language functions. Opposing the norm of a language you can find the system of a language.

\subsection{The System of a Language}

The next level in the technique of speaking in that process of abstraction extracted from the norm of a language is the system of a language. It encompasses everything objectively functional, that is, all forms keeping relationships of opposition. It virtually includes everything that is possible in a language, that is, anything having been performed and anything possibly to be performed. The system encompasses what has already been performed (that is, the usual performances, the norm of a language) plus what is possible and thus not performed or not yet performed or even what will perhaps never be performed.

The conceptual systematization of the world, the particular and peculiar way facts of experience are arranged and dealt with in a language belong to the system of that language. That is, the meanings of a language belong to the system of a language (Coseriu, 1992). For example, in Hopi (a language in Arizona, Whorf, 1956) there is no present, past or future distinction in the expression of time, nor is there the idea of space. However, there are categories unknown in other languages such a "manifesting" and "intensification". These ones constitute facts of the system of the language. Hopi people conceive the world in that way not imagining the possibility of succession of an event happening after another one. On the contrary, Westerners will conceive the world with facts occurring in accordance with the concepts of time and space.

Facts of the norm of a language and facts of the system of a language separate from each other, diverge from each other or contradict each other. They are nearer to each other when the system of a language has only one possible performance, for example, Turkish. It is usually said that anything said in Turkish is Turkish. The norm of the language in Turkish is very much like the system of the language. But this is not the case of English or Spanish, languages with long traditions in literary performances and spoken all over the world with different systems.

As with the norm of a language the system of a language extends to the four levels of language description. The phonemes are typical cases of the system of a language. Every phoneme in a language is an ideal model aimed at performance in every case. The particular performances in combination with other particular phonemes give rise to performances like the ones in examples 4, 5, 6, 7 and 8 .

Similarly, in the morphological level the system of a language is manifest in the regularity of forms and the tendency to make all forms regular. For example, in English the following two expressions can be found 
9. The bereaved, a widow and her children, were at the burial.

On the one hand,

10. The house was bereft of furniture. The widow felt herself as utterly bereft (CCELD).

Both forms bereaved and bereft are adjectives. The second one is formal. In a similar way many irregular verbs manifest the tendency to regularity, that is, the tendency to analogy thus the tendency to function in accordance with the system of a language.

11. The old building burned down easily. He spilled out his live story to a perfect stranger. They spoiled her holidays. It smelled of petrol.

4.4 The Type of a Language

The highest level in that process of abstraction referred to above with the purpose of separating the individual from the common is by the type of a language. It is the set of functional principles and relationships between procedures and functions appearing as different at the level of the system of a language. In this sense those procedures and relations appear as the ones proper or preferred to in a particular language. The type of a language encompasses the categories of factual content oppositions, functions and procedures in different systems of several languages especially in cognate languages and even in the history of a language.

\subsubsection{The Type of a Language as it Manifests Itself in Different Languages}

The type of a language can be found in both English and Spanish comparing the opposite tendency in those languages to form short and long words. In English words especially those coming from the Germanic stock tend to be one-syllabled. In Spanish the tendency is just the contrary: Spanish words tend to be long. For example, Guadalajara (five syllables), individualismo (six syllables), deliberadamente (seven syllables), otorrinolaringólogo (nine syllables). The evolution of words in the history of the English language demonstrates the tendency to shorten words. The Old English word for church was OE cyrice and this word gave two cognate words, church (the usual one) and kirk (the word in Scottish) both one-syllabled. In the same way you can see the following words: OE cnotta, ModE knot; OE fyllan, ModE fill; OE cnyttan, ModE knit; Old Germanic (tōpig) > (=becaming) OE tōp > ModE teeth; OE slógen, ModE slain, etc. The word for fear is particularly interesting. In Old English the word was ege (to be pronounced/e:je/). With contacts with the Scandinavians it disappeared and was superseded by the Scandinavian awe. Some authors interpret the fact of the disappearance of OE ege to its brevity since it would have become *ey (i:) (Barber 1995). And the same may have happened to the word for law, OE de superseded by Scandinavian lagu.

This fact has to do as well with rhythm in the utterance of a sentence. Abercrombie (Abercrombie 1967) following Kenneth L. Pike's observations (Pike 1945) distinguishes two types of languages in connection with rhythm: stress-timed and syllable-timed languages. English and Spanish are typical examples of each type. Stress-timed languages such as English give more prominence and length to the syllable stressed so that the other syllables may disappear completely or partly. Stress syllables usually occur at regular intervals of time. For example, the usual way of pronouncing the following sentence

12. What do you want to do? 


\section{MInstitute Macrothink $_{\text {Int }}$}

whould be /'what dju: 'wont $\partial$ 'du:?/ in narrow pronunciation but in broad pronunciation would

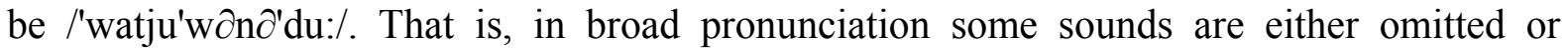
assimilated to stress sounds or even changed.

This fact can also be seen in the structure of a syllable in English and Spanish. In English a syllable may be formed with a vowel and many consonants sounds associated with it. Words like strength, nests, comfortable, worked, changed are representative examples. On the contrary in Spanish, a syllable-timed language, all syllables tend to be given equal amount of time. In this sense the typical pronunciation of Spanish is pronouncing all syllables one by one and when in writing uttering all sound symbols. As a matter of fact, this is the way pronunciation is interpreted by speakers. If a listener speaking Spanish does not understand a particular word and asks the speaker to repeat he will probably say, with the word Guadalajara, /gwa-da-la-'xa-ra/ stressing all syllables for equal even omitting the stress due.

Another example manifesting the type of a language in English is the device to create meanings with particles added to the verb in a sentence, that is, the so-called use of phrasal verbs. This device is especially manifest in present-day use in speech but has existed ever since the language was first recorded. In Old English this devised existed but differently. In Old English the formation of verbs was made with affixes (prefixes, infixes, suffixes). Thus you have $f \bar{r} r a n=$ go, afāran = to go away, ge.färan = die; niman = take, $\dot{g}$ e.niman = capture; rīsan $=$ rise, $\bar{a} r \bar{i} s a n=$ rise up; settan $=$ settle, ge.settan $=$ occupy and be.settan $=$ surround; pencan $=$ think and be.pencan $=$ consider; lucan $=$ lock and be.lucan $=$ lock up, etc. This use must have been much more frequent in speech in Old English period but there are no pieces of speech recorded. In Modern times this device is very frequent in speech especially in slang in which certain combinations of verb + particle are used with a special sense thus defining a style of speech. Examples: get, get about, get across, get after, get ahead, get along, get at, get away etc.

In connection with the creation of meanings you can see two typical ways of expressing by English and Spanish speakers. English speakers tend to be more precise and concrete in their description of things. Spanish speakers - at least in Spain - tend to be me more theoretical and abstract, not so much in connection with the real. In this sense what for a Spanish speaker is una cafetería, carnicería, librería, lavandería, un delincuente, una batería de cocina, for an English speaker is a coffee-shop, a butcher's shop, a bookshop, a dry-cleaner's, a law-breaker, pots and pans; what for a Spanish speaker is enamorarse, guisar, decidirse, for an English speaker is to fall in love, to do the cooking, to make up one's mind; what for a Spanish speaker is imbecilidad or tontería (abstract words) for an English speaker is merely non-sense; what for a Spanish speaker is el Ministerio de Asuntos Exteriores, or el Ministerio del Interior for an English speaker is merely an office: Foreing Office, Home Office. That is, for English speakers it is traditional to conceive things more thing-like, more down-to-earth. In Spanish the tradition is just the contrary, to conceive things more and more abstract in a more and more complicated way. For me, one of the greatest degrees of abstraction got in the formation of an expression is the example, precariedad laboral (=low-paid jobs) (see the role of abstraction in present-day Spanish in Martínez del Castillo 2010: 310-321, footnote 55 included). From my point of view abstraction in itself in European Spanish today (not perhaps in American Spanish) constitutes a means of expression thus a function or a tendency 
in creating words and meanings, a fact of the type of the language.

Another fact of the type of the language in English is constituted with the description of things happening in accordance with the image speakers perceive of the elements intervening in its description thus emphasizing the result. This is the case particularly with verbs of movement in English. In this sense you say

13. He bowed away; he stepped in; he moved out; he kicked the ball away; he pushed the door open; he took his boots off.

All these examples represent a description of the movements necessary to achieve the action denoted. To leave a room formally in accordance with the required signs of recognition of the authority in front of you, you first bow and when bowing you leave the room supposedly stepping backwards. To go in or out you have to step and while stepping you go in or out, etc. This way of conceiving things is especially manifest in phrasal verbs thus giving the so-called proleptic use of verbs. The proleptic use of verbs is a typical use of English verbs in which the verb states the action while the particle indicates the result. In Spanish on the contrary it is traditional to conceive the scene the other way round, first the result, and if necessary then the specification of the action:

14. Él abrió la puerta (empujándola); él mató el perro (atropellándolo); él se salió.

In the third example in 14 in accordance with the Spanish tradition of conceiving that type of an action the reflexive se is added, a means completely unnecessary, el se salió opposing el salio thus stressing the subject's intention to leave.

\subsubsection{The Type of a Language as it Manifests Itself in History: Determination in English}

The type of a language can be seen in the history of that language. The facts constituting changes in the type of a language occur in long periods of time constituting not merely facts of a language but facts of evolution. In order to illustrate this, let us analyze the character of determination in present-day English in contrast with the character of determination in Old English $\left(5^{\text {th }}\right.$ to $12^{\text {th }}$ centuries $)$.

Determination is a function to be found in all languages but differently. Some languages (English, Spanish, French, Italian) have the so-called determiners (articles, demonstratives), elements to perform the determining function. The function of determination basically consists in orientating (cf. Coseriu, 1982) the categories created in the act of knowing (Martínez del Castillo, 2011), virtual categories, to certain specifying aspects (syntactic or other) so as to make the virtual categories created adequate to the meaningful intentional purposes of the individual speaker (Martínez del Castillo, 20015b). But some languages (Latin, Russian) do not have determiners but perform the function of determination through contexts and situations, contextual determination. The problem we are posing now is the shift in the character of the determining function in the English language through its history and try to find out its causes, immediate and remote.

In Old English the determining function was executed with two devices: first, with determiners especially with the definite article, and second, with contexts and situations (contextual determination). In Old English the determining function was aimed at defining the syntactic status of the virtual categories created in the act of knowing, that is, in the individual speech act (Martínez del Castillo, 2011). With this device the categories created 
designated only categories thus neglecting what we today can call the individuality things or real things. This meant that a virtual category was restricted to refer to a particular context not mentioning the individual thing referred to. In Modern English the determining function aims at orientating the categories created in the act of knowing to things emphasizing their individuality thus making them real. This fact of evolution happened in a very long period of time involving many and different states of the language. Let us analyze the following text.

15. On his dagum sende Gregorius ūs fulluht and Columba moesse.prēost cōm tō Peohtum and hìe ge.cierde tō Crīstes ge.lēafan (The Anglo-Saxon Chronicle, anno 565).

(On his days [Pope] Gregory sent us baptism and Priest Columba came to the [land of the]

Picts and [so that] they should submit to the faith of Christ)

In this text you can find only one expression playing the determining function, Cristes ge.leafan, contextual determination. Instead of determiners you can find cases in nouns and pronouns: his, dagum, ūs, fulluht, moesse.prēost, Peohtum, hìe, and ge.lēafan. That is, the nouns in the text played the determining function with the specification of cases and genders in order to define the syntactic status to be performed by the virtual categories created in the act of speaking (dagas, fulluht, preost, hie, Peohtas and ge.leafa). This means that the determining function in Old English consisted in defining the syntactic status of categories in a phrase or a sentence. With this, the categories denoted were still categories not real things. This fact is particularly clear in Peohtum (dative plural of Peohtas). In order to make clear the determining function of this word it is necessary to paraphrase its contents, "the land of the Picts". That is and said in other words: the cases and genders in nouns, adjectives and certain pronouns played a particular type of determining function, the one orientated at defining the syntactic status in a sentence or a phrase. Today since there are no cases left and very few words with genders in the language the definition of the syntactic status in phrases and sentences is executed by means of word order.

But the tendency to the new character of the determining function, orientating virtual categories to real things (the character of determination in Modern English) appears in the Anglo-Saxon Chronicle in expressions such as Cantware and Wiht.ware, meaning "the defenders (= inhabitants) of Cantia and Wiht" respectively and especially in expressions such as Engla-land (Northern variety; Mercian variety Engla-lond,) meaning "the land of the English", Cant.wara.burg, "the city of defenders of Cant". That is, this fact speaks of the character of language changes. Language changes do not appear or disappear at once and for all. Examples like these ones can be considered as the bases for the new type of the determining function being introduced in Old English that would eventually give the type of determining function characterizing Modern English. The character of the determining function in Old English thus was double: one performed with the cases and the genders and another one with the contexts; the first one specifying the syntactic status of categories, the most important, and the second one specifying concrete objects thus creating what we now call real things.

The presence of determiners in Old English was basically reduced to the two paradigms: the one in the article and the one in demonstratives. Demonstratives had a certain adverbial content. Because of this, they cannot be assimilated to only the defining function. Let's 
analyze the ones in the articles. These ones had the following forms:

$\begin{array}{lclll} & \text { MASCULINE } & \text { FEMININE } & \text { NEUTER } & \text { PLURAL } \\ \mathrm{N} & \text { sē } & \text { sēo } & \text { pæt } & \text { pā } \\ \text { A } & \text { pone } & \text { pā } & \text { pæt } & \text { pā } \\ \text { G } & \text { pæs } & \text { pære } & \text { pæs } & \text { pāra } \\ \text { D } & \text { pǽm } & \text { pǽre } & \text { pǽm } & \text { pǽm } \\ \text { I } & \text { pý } & \text { (pǽre) } & \text { pý-pon } & \end{array}$

In the period after the Norman invasion $\left(11^{\text {th }}\right.$ to $16^{\text {th }}$ centuries) the paradigm was affected with the so-called the loss of inflexions in nouns, adjectives, certain pronouns, the article (the genders and the cases) and verbs thus reducing the determiners to a single form for all genders and numbers eventually giving the Modern English the and this/these. As said before the demonstratives had a certain value as adverbs, that make them to evolve in a different way as the article. The change was executed in the following way: (the first sound in the great majority of forms in the paradigm) $p(b<(=$ coming from) poet /poes/ poere/ pone/ $p \bar{a} /$ pone/ $b y$ - $p o n)+e$ (the ending of the singular masculine and feminine nominative case in se/seo) $>$ pe, later on transcribed as the by the Norman scribes. With this the only article in Old English was reduced to only one form and the demonstratives were strengthened with new forms poet neuter form from the article and pás $>$ tho (Elizabethan times) $>$ ModE those (Baugh \& Cable, 2002)

\subsubsection{The Determination and the Meaningful Intentional Purposes of Speakers}

This fact makes us pose the following problem, was the determining function reduced? Not at all: it changed and was strengthened. Why was the determiner affected with such reduction?

The real change happened in the determining function was notional. It was prompted by the new meaningful intentional purpose of speakers at the time. It consisted in orientating virtual categories to objects making them real things. This new intentional purpose of speakers made the old forms in the article no longer necessary. As it was said above the Old English determiner orientated virtual categories to the syntactic status they performed in a sentence or phrase, a function having to do with the combination of words. For example, if in present day English you say, give me the book, you refer to a particular item of the virtual category of things denoted with the word book, a real book, orientated not to the syntactic function played in the phrase or sentence but to a real object. The interest of the speaker and the attention of the speaker is directed to the object denoted, not to the syntactic statues the category represented in a word was going to perform. Since the article had to be in concord with nouns it attracted nouns to have only one form for the singular and another one for the plural. That is, the shift in the orientation of the determining function made the cases and genders unnecessary. Speakers thought of things instead of categories. It is licit then to interpret the language change called the loss of inflexions as the result of the new orientation of virtual categories to things, thus making them real. The most immediate result of this is that the word order got functional import. Today word order in itself constitutes a function in the English language.

The pronouns contributed as well to the change in the determining function. The change in the determining function had to do as well the with re-establishment of a new set of personal 
pronouns in the third person singular, but realize, in the third person, not in the first and second persons. Since the syntactic status of nouns was no longer necessary to be expressed the third personal pronouns were assimilated to a function similar to the one performed by the article the. Since the third person personal pronouns separated the masculine, feminine and neuter forms the neuter, hit, was assimilated to the article thus making a new distinction, the living as different from non-living. As a result, the paradigm of personal pronouns in the third person singular was restructured separating the masculine from the feminine and assimilating hit to refer to things as if was an article. So with the same procedure of combining forms a new personal pronoun for the feminine was created, the old article sēo (nominative feminine singular) $+h \bar{e} o$ (the old personal pronoun third person nominative feminine singular $>$ scae (Eastern Midlands) > Middle English scho / sho / she (Northern variety), a word combining both the determining function and the character of a living being to be applied to humans. From the early $13^{\text {th }}$ century on the concepts having to do with women were referred to with she. Previously wif-man (=woman) was neuter in Old English and later on masculine.

\subsubsection{Determination and the Character of Personal Pronouns}

These facts make us think of the character of the so-called personal pronouns in the third person. We can pose the following problem, why did the determining function affect both the determiner and the personal pronouns third person singular and not the first and second personal pronouns singular?

The problem can be formulated with the following question, how do articles and third person personal pronouns bear with one another? Two reasons can be given, one linguistic and the other one having to do with the human life. From a linguistic point of view, the problem has to do with the principle of the required equilibrium in a system. A language is a system in a permanent unstable equilibrium based on paradigmatic and syntagmatic relationships of solidarity. When a particular part of a system is modified then there will be un-stability in another part of that system and will be re-structured as well. This means that the systems affected were part of a larger system, that is, third person personal pronouns belong to the same category as determiners. But the problem still lingers. From the point of view of the human reality it is licit to ask why, why did the determining function prompt the change in the third person personal pronouns and not in the second and first personal pronouns?

The answer is that third person personal pronouns are not personal pronouns but merely determiners (Benveniste 2007 and Ortega y Gasset 2001). Third person personal pronouns belong to grammar, not to the speech act, the living reality creating language. The only personal pronouns are the $I$ and the You, that is, those creating the speech act, that is, creating dialogue,

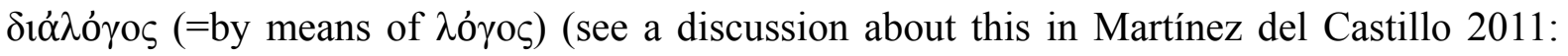
221-227).

\subsubsection{Determination and Adjectives}

The fact of determination being played by nouns by means of cases and genders in Old English can be put in connection with the evolution of adjectives. Adjectives could be strong and weak in Old English. They were weak when they were preceded by a determiner otherwise they were strong. Example, gōd (strong, nominative for all genders) vs. gōd, gōde, gōd (weak, nominative masculine, feminine and neuter). The influence of the article on 
adjectives was decisive: the presence of the article determined the character of the adjective. Two reasons can be given to explain this fact. First, since the determining function was to orientate categories to the status they performed in a phrase in Old English or sentence that function was performed by nouns perfectly well. But the role of nouns and the determiner had changed. So adjectives could not interfere in the function performed by nouns and the article since they all appeared in the same phrase. Because of this, adjectives became indeclinable, that is, not defined in terms of the old determining function. They did not convey any case because that function was no longer necessary. There could not be contradiction in the sentence or the phrase. The noun with the article played the determining function orientating virtual categories to real things. Adjectives thus acquired predicative function only. They were applied to a noun and conveyed a modifying meaningful function on their headwords. So the adjective was dispossessed of any determining function thus reaffirming it in the adjectival function. Because of this the adjective today must be specified somehow when used alone in a phrase, for example, the blue one, the destitute, the English, the white in the mountains, etc.

\subsubsection{Determination and Numeral One}

As part of this re-structuring in the determining function other changes must be mentioned. The Old English numeral $\bar{a} n$ started being used (early $13^{\text {th }}$ century on) together with a reduced form of it as an indefinite determiner thus giving the forms an, on, $a$, later on being separated from the numeral one. With this the language had a new particularizing device, one, to refer to things thus reinforcing the determining function of orientating virtual categories to real things.

\subsubsection{Contextual Determination in English}

On the other hand, the contextual determining function in English was reinforced using different grammatical and syntactic means. In the text above the expressions, on his dagum and Crīstes ge.léafan appear. His in the first expression was not a determiner but a personal pronoun, a fact already analyzed. Crīstes in Crīstes ge.lēafan as a proper name played a certain determining function the same as with many other nouns in the genitive preceding another noun, contextual determination. Similar expressions today are considered to be determiners, Peter's house. Contextual determination constitutes a tendency in English today thus making possible expressions like

16. Her father in law's car. The King of England's eldest son. The man I saw yester-day's wife,

The following example would sound a bit strange in the Western World if you bore in mind the nature of the things involved

\section{She is a wife of Peter's.}

That is, the model of this type of structure is just a fact of the type of the language in English having survived in the different states of the language and manifesting in different types of combinations for a very long period of time. With this again we can pose another problem, why did the character of determination change?

\subsubsection{Determination, Categories and the Substantive Mode of Thinking in English}

The determining function constitutes a fact of evolution in the English language manifest since the language was first recorded. The shift in the character of the determining function in 
English was prompted with the change in the mode of thinking of its speakers. The so-called Anglo-Saxons had had some contacts with the Romans on the continent. The proof of this initial contact is constituted with the so-called changes, $i$-umlaut, $i$-mutation or front mutation, dipthong ai and diphthong au in Old Germanic (Barber 1995; Martinez del Castillo 2006). These sound changes occurred on the continent in the first to third centuries but manifest themselves in Old English. However front mutation affected the Latin word Cantia when the Anglo-Saxons were firmly established in the island. This place name could not have been known by the Anglo-Saxons when they were on the continent since they were illiterate. It gave Cent (Kent), Cent-land and Cant-wara-burg (=the city of the defenders of Cantia) hence Canterbury. This means that the influence exercised by front mutation on the people speaking the language was really strong: beyond the sound changes was something worth considering and guessed out. What was it?

The writings of the Anglo-Saxons when come to the island manifested the way of rendering the Christian and Roman concepts into Old English later on strengthened with the Christening of Britain by priest Columba in the $6^{\text {th }}$ century (Annal 565, The Anglo-Saxon Chronicle). In both moments these concepts were translated in accordance with the way of thinking the Anglo-Saxons had at the time. The Latin word Trinitas was first rendered as prines (="something becoming three"), that is, the OE word prines revealed a dynamic conception of things in contrast with the static conception denoted by the Latin word. The same dynamic conception of things can be seen in the following words: bōccraft $<$ bōc + cræft =book-skill, the technique of writing, rimcraeft (number-skill), the technique of dominating the numbers; or tungolcraft (tongue-skill), the technique of dominating speech; stcercraeft (star-skill $=$ the technique of dominating stars). These Anglo-Saxon words refer respectively to writing, arithmetic, the technique of speaking and astrology. That is, people speaking Old English emphasized the fact having to do with the production of respectively writing, calculating, speaking, creating the knowledge about stars. They denoted, not the knowledge implicit in writing, calculating, speaking or the stars (something considered static) but the competence (ability involving both knowledge and activity) implicit in those types of knowledge. Their way of thinking was dynamic, not static.

But in the period after the Norman Invasion $\left(11^{\text {th }}\right.$ to $15^{\text {th }}$ centuries) these words and many others were rendered again into English not with Anglo-Saxon roots but adopting Latin origin words, trinity, writing, arithmetic, language, astrology. The new rendering matched much better with the concepts explained in churches, cathedrals and universities at the time. The new words distinguished from the Anglo-Saxon ones in that they answered to a new static and objective way of conceiving things. Arithmetic, language, and astrology were considered as if they denoted existing and independent realities, not the living reality (competence) they all involve. On the other hand, all words introduced in the language in the thirteenth and fourteenth centuries denoted new realities conceived statically. For example, justice was introduced in the language superseding ge.rihte $=($ the act of correcting together with someone else (prefix ge- with nouns denoted company), correction); judgement superseding dom (=pronouncing a sentence, sentence); crime superseding un.dćd (=not a good action); innumerable superseding un.ā.rìm.ed-lic (=prefix un- (negation) + infix $-\bar{a}$ - (ever, indefinite sense) + noun rim (number) + suffix -ed (suffix forming adjective-like words) + suffix -lic 
(suffix added to nouns to form adjectives), that is, "never becoming number-like) etc. (cf. Martínez del Castillo, 2006). That is, the new words represented the adoption of a new mode of thinking with the implicit new mode of conceiving things. Things were no longer conceived as as categories but as real objects, that is, things existing in themselves, that is, entities. Countries and cities were no longer referred to their inhabitants (no longer defenders, see Columba cōm tō Peohtum, example above) but places. Things were no longer the concrete application of concepts (categories). Things existed as processes not individual things (cf. Martínez del Castillo 2015k). As we saw earlier the determining function in Old English did not give real things but would determine virtual categories in as much as they were going to play a particular syntactic function. The new mode of thinking and the new mode of conceiving things in the thirteen and fourteenth centuries was prompted as well by the new interest for nature and natural things (remember that in the thirteenth and fourteen centuries there appeared an increasing interest for nature in literature, painting the arts and even in the religious conception of life as in Saint Francis of Assissi, 1181-1226). Linguistically speaking the interest in language expression was to focus on individual things now considered to exist in themselves as individual entities.

The changes suffered in the Western Europe during the middle ages meant the assimilation of the mode of thinking of the Greek, an old civilization having started in the $7^{\text {th }}$ century $\mathrm{BC}$, later on to be broadcast by Romans and the Christening of Europe in its different forms. The Greek with Parmenides of Elea and Heraclitus of Ephesus ( $6^{\text {th }}$ century BC) created the concept of being as the category giving support to the existence of individual things, that is, individual things were made entities they all bearing being in themselves. Plato $\left(5^{\text {th }}-4^{\text {th }}\right.$ century BC) created the concept of lógos, that is, the concept of ideas that would represent objects surrounding humans. And Aristotle $\left(4^{\text {th }}\right.$ century BC) redefined both concepts creating a new one, the concept of substance, something existing in itself not needing of anything else to exist. Things were conceived as abstract categories existing in so far as they were substances. This mode of thinking transported into the Anglo-Saxon world would create the problem of universals in the islands in the $14^{\text {th }}$ century: are universals (categories) substances? (William Ockham (1290-1349), a problem that would eventually give rise to the modern or Cartesian mode of thinking by Descartes (1596-1540) and Galileo (1564-1642).

For a language with a dynamic conception of things as the one spoken by the Anglo-Saxons in order to adopt the new mode of conceiving things it was necessary to create determiners that would facilitate conceiving things as individual objects more in connection with the first or concrete apprehension of things through the senses. That is, Anglo-Saxons changed their mode of thinking and the implicit mode of conceiving things. They adopted the substantive mode of thinking (Ortega y Gasset, 1992a; Martínez del Castillo, 2013). The did no longer conceive ideas representing categories and determining them to play a particular syntactic function in the sentence or the phrase (primitive way of thinking). They conceived the individuality of objects represented with the ideas of Plato considering them objectively and existing individually (entities, Parmenides and Heraclitus) thus executing categories (substances, Aristotle) to be applied in the act of knowing to individual objects and determining the syntactic status to be played by them with word-order (see Martínez del Castillo, 2013; Martínez del Castillo, 2015j; Martínez del Castillo, 2015k; Ortega y Gasset, 
1992a and Ortega y Gasset, 2005). The means to achieve the new mode of thinking and the implicit mode of conceiving things was determination adopting the new determiners created (the, a/an) and using word order as a new means of expression.

The conclusion to be drawn from these facts considered under the point of view of the type of the English language is that the determining function prompted a series of changes, formal changes (the loss of inflexions, the re-structuring of the genders, the creation of new determiners, the replacement of old words for words coming from the Latin world) involving the adoption of new concepts orientating virtual categories to real objects in accordance with the great discovery in the thirteenth and fourteenth centuries, the love for nature. With this real language started to be of interest in the linguistic expression of old Anglo-Saxons. In a word: they adopted the new mode of thinking coming from the Greek. The adoption of the new mode of thinking gave rise to the dispute about universals just in the British Isles posed by William Ockham referred to above. The determining function thus constitutes a fact of the type of the English language. Considering the depth of the changes suffered and the long period of time needed in that adoption ( $11^{\text {th }}$ to $17^{\text {th }}$ centuries included) the determining function constitutes a fact of evolution in the English language.

\subsubsection{The Subjunctive and the Type of the Language in English}

In example 15 the subjunctive appears, and hie ge.cierde tō Crīstes ge.lēafan. The subjunctive in Old English had much more importance than today but it still survives in expressions such as the committee proposed that Mr Day be elected (mandative subjunctive); come what may, we will go ahead with our plan (formulaic subjunctive); and if that be the official view it cannot be accepted (the subjunctive in subordinate clauses, condition and concession); the President must reject this proposal, lest it cause strife and violence (the subjunctive in subordinate clauses, negative condition); if I were rich I would give you anything you wanted (the subjunctive in subordinate clauses, hypothetical or unreal) (Quirk and others 1985). The existence of the subjunctive today constitutes a fact of the type of the language. The function still persists although in a different way.

\subsection{An Open Technique}

The type of a language constitutes the highest level of abstraction in the technique of speaking. The system of a language goes beyond the norm of a language and the type of a language goes beyond the system of a language. The norm of a language encompasses the facts actually performed. The system of a language encompasses both the facts performed and the possible ones in accordance with the facts of opposition given. And the type of a language makes possible not only the principles and oppositions existing but at the same time many other probable principles not created yet or even principles never to be created.

In this way every language is an open technique, a dynamic technique partly performed and partly to be performed. In connection with the system of a language a language is a system of possibilities. In connection with the norm of a language a language is a set of usual performances offered to speakers. What has already been performed is nothing absolute but contingent. It is merely the manifestation of the possibilities of performance of that technique of speaking, that uncommitted technique for any possible speech (Coseriu, 1992; Coseriu, 1987). And in connection with the type of a language a language is a set of isoglosses 


\section{Macrothink}

(=common speech acts) developing in history.

The norm of a language can be modified in the synchronic axis of a language while the system is unalterable in that axis. The system of a language can be modified in different states of a language, that is, in the evolution of the language, diachronic axis. And the principles, tendencies and functions of the type of a language can be modified in very long periods of time encompassing some or many states of a language. Language thus is and will always be a system (Coseriu, 1992).

\section{Importance of Levels in the Configuration of Speaking}

The levels of the configuration of a functional language are the condition for speakers to make a creative use of their idiomatic knowledge thus enlarging and developing their idiomatic knowledge. The technique of a language as a complex of functions and procedures is the guarantee for the continuity of a language.

\section{Conclusion}

In speaking a human subject manifests himself as an intelligent subject who creates language in speech, that is, a historical subject who creates a historical object. Because of this and considering the historical condition of humans of being-together-with-others idiomatic knowledge is both structured and common.

\section{References}

Abercrombie, D. (1967). Elements of general phonetics. Edinburg: Edinburg University Press.

Baugh, A. C. (1957). A History of the English Language. London: Routledge and Kegan Paul. Baugh, A. C. and Thomas Cable. (2002). A History of the English Language. London: Routledge and Kegan Paul.

Barber, C. (1995). The English Language: A Historical Introduction. Cambridge University Press.

Blake, N. (1996). A History of the English Language. Macmillan. http://dx.doi.org/10.1007/978-1-349-24954-1

Bosworht, J. (1995). An Anglo-Saxon Dictionary: Based on the Manuscript Collections of Joseph Bosworth. T. Northcote Toller, ed. Oxford University Press.

Bloomfield, L. (1976). Language. London: Allen \& Unwin.

Chomsky, N. (1957). Syntactic Structures. The Hague and Paris: Mouton.

Chomsky, N. (1965). Aspects of the Theory of Syntax. Cambridge MA: MIT Press.

Chomsky, N. (1984). Reflections on Language. Spanish translation (1984). Barcelona: Planeta-Agostini.

Collins Co-Build English Language Dictionary.

Coseriu, E. (1952). Sistema, norma y habla (System, norm and speech). Montevideo. Published in Coseriu 1982.

Coseriu, E. (1977). Tradición y novedad en la ciencia del lenguaje: estudios de historia de la lingüistica (Tradition and innovation in language science: studies in the history of linguistics). Madrid: Gredos. 


\section{Macrothink

Coseriu, E. (1981). Principios de semántica estructural (Principles of structural semantics). Madrid: Gredos.

Coseriu, E. (1982). Teoría del lenguaje y lingüistica general (Theory of language and general linguistics). Madrid: Gredos.

Coseriu, E. (1985a). El hombre y su lenguaje: estudios de teoría y metodología lingüística (Man and his language: studies in linguistic theory and methods). Madrid: Gredos.

Coseriu, E. (1985b). Linguistic Competence: What is it Really? The Modern Language Review, 80 (4).

Coseriu, E. (1986a). Introducción a la lingüística (Introduction to linguistics). Madrid: Gredos.

Coseriu, E. (1986b). Lecciones de lingüistica general (Lessons in general linguistcs). Madrid: Gredos.

Coseriu, E. (1987). Gramática, semántica, universales: estudios de lingüistica funcional (Grammar, semantics, universals: studies in functional linguistics). Madrid: Gredos.

Coseriu, E. (1988). Sincronía, diacronía e historia: el problema del cambio lingüístico (Synchrony, diachrony and history: the problem of language change). Madrid: Gredos.

Coseriu, E. (1990). "Semántica estructural y semántica cognitiva" (Structural semantics and cognitive semantics). Homenaje al Profesor Francisco Marsá/Jornadas de Filología. Colecció homenatges. Universidad de Barcelona: 239-282.

Coseriu, E. (1992). Competencia lingüistica: elementos de la teoría del hablar (Linguistic competence: elements of the theory of speaking). Madrid: Gredos.

Dik, S. C. (1978). Functional Grammar. Amsterdam: North-Holland. Traducción española, (1981).

Humboldt, Wilhelm von. (1990). Sobre la diversidad de la estructura del lenguaje humano y su influencia sobre el desarrollo espiritual de la humanidad (On the diversity of the structure of the human language and its influence on the spiritual development of Mankind). Madrid: Anthropos \& Ministerio de Educación y Ciencia.

Martínez del Castillo, Jesús. (2006). Facts of Speech and Facts of Evolution. An Interpretation to the English Language. Abecedario.

Martínez del Castillo, Jesús. (2010). Las relaciones lenguaje-pensamiento o el problema del logos (The relationships in language and thought or the problem of lógos). Madrid: Biblioteca Nueva.

Martínez del Castillo, Jesús. (2011). Sobre las categorías (Discussion on categories). Buenos Aires: Deauno.com

Martínez del Castillo, Jesús (2012). Psicología, lenguaje y libertad (Psychology, language and freedom). Málaga: Analecta Malacitana, 89.

Martínez del Castillo, Jesús. (2013). Modes of Thinking, Language and Linguistics. Malaga: Analecta Malacitana, 94.

Martínez del Castillo, Jesús. (2015a). Linguistics of Saying. Presentation. International Journal of Language and Linguistics. Special Issue, Linguistics of Saying, 3, (6-1), 1-4.

Martínez del Castillo, Jesús. (2015b). The Meaningful Intentional Purpose of the Individual 


\section{Macrothink Institute ${ }^{\mathrm{m} M}$}

Speaker. International Journal of Language and Linguistics. Special Issue, Linguistics of Saying, 3(6-1), 5-10.

Martínez del Castillo, Jesús. (2015c). The Process of Abstraction in the Creation of Meanings. International Journal of Language and Linguistics. Special Issue, Linguistics of Saying, 3(6-1), 11-23.

Martínez del Castillo, Jesús. (2015d). Fixing the Content Created in the Act of Knowing. International Journal of Language and Linguistics. Special Issue, Linguistics of Saying, 3(6-1), 24-30.

Martínez del Castillo, Jesús. (2015e). The Speech Act as an Act of Knowing. International Journal of Language and Linguistics. Special Issue, Linguistics of Saying, 3(6-1), 31-38.

Martínez del Castillo, Jesús. (2015f). Determining the Degree of Reality of Language. International Journal of Language and Linguistics. Special Issue, Linguistics of Saying, 3(6-1), 39-49.

Martínez del Castillo, Jesús. (2015g). Meaning and Language. International Journal of Language and Linguistics. Special Issue, Linguistics of Saying, 3(6-1), 50-58.

Martínez del Castillo, Jesús. (2015h). The Activity of Speaking. International Journal of Language and Linguistics. Special Issue, Linguistics of Saying, 3(6-1), 59-66.

Martínez del Castillo, Jesús. (2015i). Meaning, What Is It. International Journal of Language and Linguistics. Special Issue, Linguistics of Saying, 3(6-1), 67-76.

Martínez del Castillo, Jesús. (2015j). Modes of Thinking in Language Study. International Journal of Language and Linguistics. Special Issue, Linguistics of Saying, 3(6-1), 77-84.

Martínez del Castillo, Jesús. (2015k). Modes of Thinking and Language Change: The Loss of Inflexions in Old English. International Journal of Language and Linguistics. Special Issue, Linguistics of Saying, 3(6-1), 85-95.

Martínez del Castillo, Jesús. (20151). Categories and Language. International Journal of Language and Linguistics. Special Issue, Linguistics of Saying, 3(6-1), 96-104.

Martínez del Castillo, Jesús. (2015m). Linguistics as a theory of knowledge. Education and Linguistics Research, 1(2), 62-84. http://dx.doi.org/10.5296/elr.v1i2.8368

Martínez del Castillo, Jesús. (2016a). Real Language. Education and Linguistics Research, 2(1), 40-53. http://dx.doi.org/10.5296/elr.v2i1.8832

Martínez del Castillo, J. (2016b). Studying Linguistic Competence. The Problem. Education and Linguistics Research, 2(1), 85-97. http://dx.doi.org/10.5296/elr.v2i1.9157

Martínez del Castillo, J. (2016c). Identifying Linguistic Competence. What Linguistic Competence Consists In. Education and Linguistics Research, 2(1), 120-141. http://dx.doi.org/10.5296/elr.v2i1.9337

Martínez del Castillo, J. (2016d). The Hermeneutics of Speaking. What Linguistic Competence Consists Of. Education and Linguistics Research, 2(1), 142-164. http://dx.doi.org/10.5296/elr.v2i1.9337

Martínez del Castillo, J. (2016e). The Nature of Idiomatic Knowledge. Education and Linguistics Research, 2(2), 18-26. http://dx.doi.org/10.5296/elr.v2i2.9442

Ortega y Gasset, J. (1992a [1958]). La idea de principio en Leibniz (The idea of principle in 


\section{Macrothink}

Education and Linguistics Research

ISSN 2377-1356 2016, Vol. 2, No. 2

Leibniz). Alianza Editorial.

Ortega y Gasset, J. (1992b [1984]). ¿Qué es conocimiento? (What is Knowledge). Alianza Editorial-

Ortega y Gasset, J. (1994 [1957]). ¿Qué es filosofía? (What is Philosophy). Alianza Editorial.

Ortega y Gasset, J. (1996 [1979]). Sobre la razón histórica (Discussion on the Historical Reason). Alianza Editorial.

Ortega y Gasset, J. (2001). El hombre y la gente (Man and people). Alianza Editorial

Ortega y Gasset, J. (2002 [1982]: 192-233) "En torno al coloquio de Darmstadt" (Discussion on the Darmstadt Colloquium), in Meditación de la técnica y otros ensayos de ciencia y filosofía. Alianza Editorial.

Ortega y Gasset, (2009), “Apuntes para un comentario al banquete de Platón“, (Notes for a comment to Plato's Symposium). Obras completas, IX, Taurus, 2009: 729-758.

Ortega y Gasset, J. (2005 [1933]): En torno a Galileo. Madrid: Biblioteca Nueva.

Partridge, Eric. (1966). Origins, An Etymological Dictionary of Modern English. Londres: Routledge \& Kegan Paul.

Pike, Keneth Lee. (1945). The Intonation of American English. East Lansing: University of Michigan Press.

Quirk, R., Sidney, G., Geoffrey, L., \& Jan Svartvik. (1985). A Comprehensive Grammar of the English Language. Longman.

Saussure, Ferdinand de. (1974). Curso de lingüistica general (Course de linguistic génëral). Buenos Aires: Losada.

Sweet, H. (1970). Sweet's Anglo-Saxon Primer. Norman Davis, ed. Oxford: Clarendon Press.

Whorf, B. L. (1956). Language Thought and Reality: Selected Writings of Benjamin Lee Whorf. J. B. Carroll, ed. Cambridge Massachusetts: The MIT Press.

\section{Copyright Disclaimer}

Copyright reserved by the author(s).

This article is an open-access article distributed under the terms and conditions of the Creative Commons Attribution license (http://creativecommons.org/licenses/by/3.0/). 